\title{
Numerical Modelling of Stress-Strain Analysis in Underground Thick Coal Mining
}

\author{
Mustafa E. Yetkin ${ }^{1 *}$, Ahmet T. Arslan ${ }^{2}$, M. Kemal Özfirat ${ }^{1}$, Bayram Kahraman $^{1}$, Hayati Yenice ${ }^{1}$ \\ ${ }^{1}$ Dokuz Eylul University Mining Engineering Department, Turkey \\ ${ }^{2}$ Dokuz Eylul University Izmir Vocational School Technical Programs Department, Turkey
}

\begin{abstract}
Thick coal mine operations have various methods. If the thick coal seam cannot be mined by single pass longwall (SPL), then Longwall top coal caving (LTCC) method or multi slice longwall (MSL) can be employed. In Turkey, caving methods are commonly used in mining of thick coal seams as long as the roof strata are suitable for their use. Longwall with caving is always preferred to filling methods because of its simplicity, favorable economics. In the literature, underground production methods are studied oftenly on the contrary rock mechanics and roof conditions. Rock mechanics and roof strata conditions examining with Finite Element Methods (FEM) are very important in terms of efficiency and continuous production. In this study, FEM analysis are made for thick coal mining methods. Numerical modelling from the field for laboratory tests on samples obtained after the Mohr-Coulomb and/or Hoek-Brown rock failure criteria determining the rock mass properties modeling has been performed. Similar strain values are computed in front of the face in all three methods considered. However, when stress-strain values on the gob area are measured, stress-strain distribution in lower face method is found to be more stabilized and proper.
\end{abstract}

Keywords: Thick coal mining, longwall, numerical modelling, face, gob.

\section{INTRODUCTION}

In many of the countries on the world, lignite coal is still one of the major energy resources. World lignite coal production is $905 \mathrm{Mt}$ in 2012 according to the International Energy Agency (IEA, 2013c). In addition, lignite coal production of Turkey is 68.1 Mt in the same year. 33.3 Mt of this production is mined by Turkish Coal Institution (TKI), 28.5 Mt is mined by EUAS (Electricity Generation Company) and the rest by private companies. Total lignite reserves of Turkey amount to approximately $14 \mathrm{Gt}$ in recent years which constitutes $1.52 \%$ of total world reserves. In Turkey, caving methods are mostly employed in mining of thick coal seams as long as the roof strata are suitable for their use. Longwall with caving is always preferred to stowing faces because of its simplicity, favorable economics, and high productivity. It is assumed that the upper bound of applying SPL method as a mechanized system in thick coal seams is about $6 \mathrm{~m}$. If the thick coal seam cannot be mined by SPL method, then MSL method can be employed (Peng and Chiang, 1984; Singh and Singh, 1999; Hartman and Mutmansky, 2002; Hebblewhite and Cai, 2004; Simsir and Ozfirat, 2008). LTCC and MSL methods are given in Figure 1.

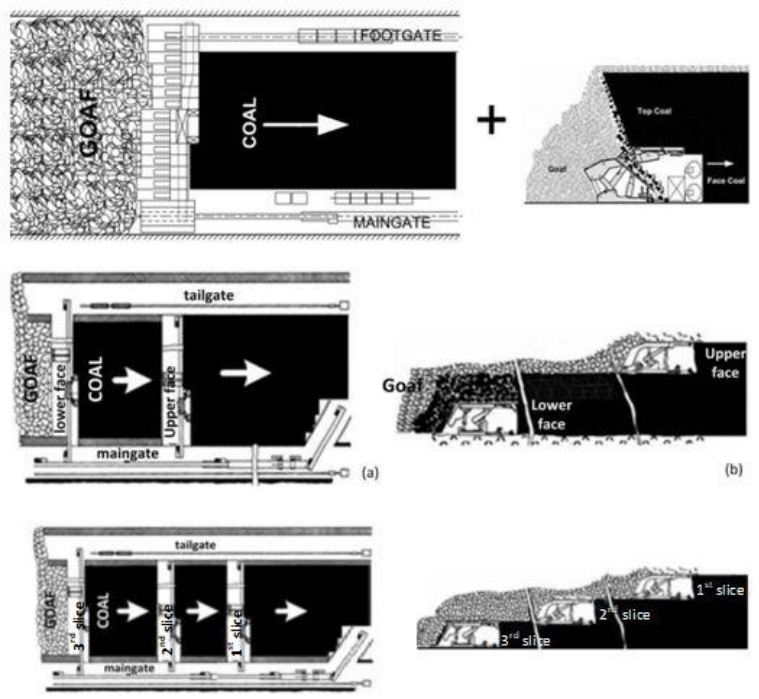

Figure 1. Production methods of thick coal seams

In this study, stress analysis is investigated for production methods of thick coal seams using Phase 2D which is a twodimensional stress analysis software. The production method used in the current system, which is LTCC from bottom face method, is modelled and the stress values are found. Then alternative production methods which are lower-upper face and sliced methods are modelled. In all three methods handled, minimum vertical stress is found on the face. But, LTCC from bottom face method is more advantageous than other methods according to the stress analysis results. Stress values on the face, in front of the face and rear face in this method lower than others. LTCC from bottom face method (current method in mine) is found to be preferable method compared to others.

\section{STUDY FIELD}

Omerler Underground Mine is in the inner Aegean District of Turkey near Tuncbilek-Tavsanl, Kutahya area and belongs to Turkish Coal Enterprises (Figure 2). The total proven lignite reserve in the district is about 330 million tons. The average depth is approximately $240 \mathrm{~m}$ below surface. The thickness of the coal seam is 8m with a slope of 10o (Taskin, 1999; Destanoglu et al., 2000; Yasitli, 2002; Yasitli and Unver, 2005, Ozfirat, 2007). 


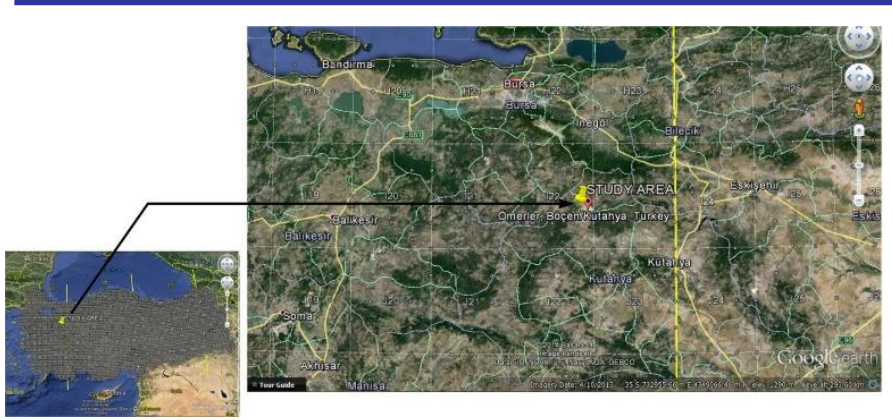

Figure 2. Location map of the study field

A generalized lithologic column showing the coal seam together with roof and floor strata is given in Fig. 3. There are three main geological layers in the mine area which are claystone, clayey marl and marl (Destanoglu et al., 2000). Physical and mechanical characteristics of coal and surrounding rock are presented in Table 1 (Kose et al., 1994; Taskin, 1999, Destanoglu et al., 2000, Yasitli, 2002, Yasitli and Unver, 2005, Ozfirat, 2007).

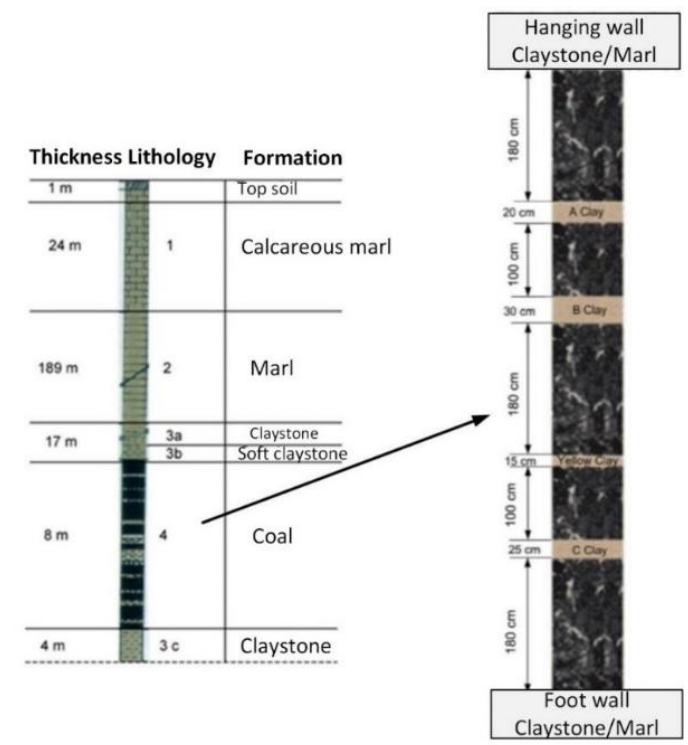

Figure 3. A generalized and coal seam stratigraphic column at Omerler Coal mine

Coal has been produced by means of longwall retreat with the top-coal-caving production method where a $3 \mathrm{~m}$ high longwall face was operated at the floor of the coal seam (Fig. 4). Topslice coal having a thickness of $5 \mathrm{~m}$ was caved and produced through windows located at the top of the shields. Fig. 4 gives the plan (a) and the cross-sectional views (b) of the longwall. In addition roof support properties are given in Table 1 (Destanoglu et al, 2000; Simsir and Ozfirat, 2008).

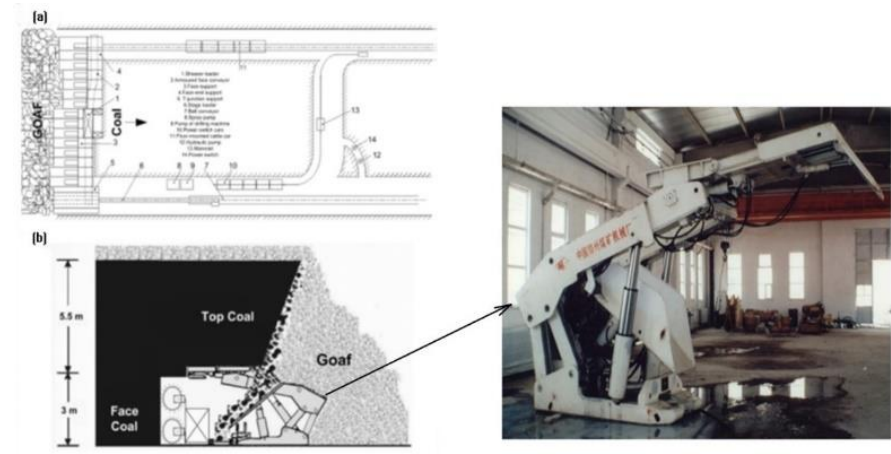

Figure 4. Plan (a) and cross-sectional view (b) of the longwall

Table 1. Properties of Face Supports

\begin{tabular}{|l|l|}
\hline Type & ZYD 4000/18/32 \\
\hline Support height Min, Max. $(\mathrm{mm})$ & $1800-3200$ \\
\hline Support width $(\mathrm{mm})$ & 1500 \\
\hline Strength of working $(\mathrm{kN})$ & 3300 \\
\hline Yielding Load $(30 \mathrm{MPa}$ Pump pressure, $\mathrm{kN})$ & 2804 \\
\hline Support density $\left(\mathrm{kN} / \mathrm{m}^{2}\right)$ & 865 \\
\hline Window dimension $($ length $\times$ width, $\mathrm{mm})$ & $1750 \times 800$ \\
\hline Mass $(\mathrm{kg})$ & 16200 \\
\hline
\end{tabular}

Material properties should be evaluated carefully in order to find satisfactory results in modeling with PHASE2D. That's why, physical and mechanical properties of each stratum should be studied in detail. Generally, first laboratory experiments are carried out to find intact rock properties. However, there is an important difference between rock material and rock mass properties. Therefore, it is important to use rock mass properties instead of rock material properties in numerical modelling. Physical and mechanical properties of intact rock material are given in Table 2 (Destanoglu, 2000; Yasitli, 2002; Yasitli and Unver, 2005; Kose et al, 1994; Ozfirat, 2007).

Table 2. Physical and mechanical properties of intact coal and surrounding rocks

\begin{tabular}{|c|c|c|c|c|c|c|}
\hline Properties & $\begin{array}{c}\text { Calcareous } \\
\text { Marl }\end{array}$ & Marl & $\begin{array}{c}\text { Roof } \\
\text { Claystone }\end{array}$ & $\begin{array}{c}\text { Floor } \\
\text { Claystone }\end{array}$ & $\begin{array}{c}\text { Soft } \\
\text { Claystone }\end{array}$ & Coal \\
\hline $\begin{array}{c}\text { Unit } \\
\text { weight } \\
(\gamma) \\
\left(\mathrm{MN} / \mathrm{m}^{3}\right)\end{array}$ & 0.023 & 0.022 & 0.021 & 0.024 & 0.023 & 0.013 \\
\hline $\begin{array}{c}\text { Uniaxial } \\
\text { comp. } \\
\text { strength } \\
\left(\sigma_{\mathrm{c}}\right) \\
(\mathrm{MPa})\end{array}$ & 29.2 & 16.1 & 12.00 & 24.50 & 11.52 & 12.15 \\
\hline $\begin{array}{c}\text { Young's } \\
\text { modulus } \\
(\mathrm{Ei})\end{array}$ & 5520 & 2530 & 2785 & 3204 & 1669 & 1748 \\
$(\mathrm{MPa})$
\end{tabular}

After determining physical and mechanical properties of intact rock, properties of rock mass are derived from these values using empirical relations from the literature. Some of the mostly used equations belong to Hoek and Brown (1997) failure criterion, Bieniawski's in 1973 and 1989 RMR classification system, and Geological Strength Index (GSI) (Hoek, 1995; 
Sonmez and Ulusay, 1999). Rock mass properties are given in Table 3 (Yasitli and Unver, 2005; RocData, 5.0; Kanık et al, 2015; Alemdağ et al, 2015; Folorunso et al, 2015, Wang and $\mathrm{Ni}, 2014)$.

Table 3. Rock mass properties of coal and surrounding rocks

\begin{tabular}{|c|c|c|c|c|c|c|}
\hline Properties & $\begin{array}{c}\text { Calcareous } \\
\text { Marl }\end{array}$ & Marl & $\begin{array}{c}\text { Roof } \\
\text { Claystone }\end{array}$ & $\begin{array}{c}\text { Floor } \\
\text { Claystone }\end{array}$ & $\begin{array}{c}\text { Soft } \\
\text { Claystone }\end{array}$ & Coal \\
\hline $\begin{array}{c}\text { Geological } \\
\text { Strength Index } \\
\text { GSI }\end{array}$ & 45 & 45 & 32 & 41 & 32 & 29 \\
\hline $\begin{array}{c}\text { Hoek-Brown } \\
\text { constant mi }\end{array}$ & 13 & 9 & 7 & 6 & 12 & 5 \\
\hline $\begin{array}{l}\text { Disturbance } \\
\text { Factor (D) }\end{array}$ & 0.7 & 0.7 & 0.7 & 0.7 & 0.7 & 0.7 \\
\hline $\begin{array}{l}\text { Hoek-Brown } \\
\text { constant mb }\end{array}$ & 0.633 & 0.438 & 0.167 & 0.235 & 0.238 & 0.103 \\
\hline $\begin{array}{c}\text { Hoek-Brown } \\
\text { constant s }\end{array}$ & 0.0003 & 0.0003 & 0.0001 & 0.0002 & 0.0001 & 0.000034 \\
\hline $\begin{array}{c}\text { Hoek-Brown } \\
\text { constant a }\end{array}$ & 0.508 & 0.508 & 0.520 & 0.511 & 0.520 & 0.524 \\
\hline $\begin{array}{c}\text { Tensile } \\
\text { strength ot } \\
\text { (MPa) }\end{array}$ & -0.0159 & -0.0127 & -0.0042 & -0.0202 & -0.0025 & -0.0040 \\
\hline $\begin{array}{l}\text { Uniaxial } \\
\text { comp. } \\
\text { strength } \sigma \mathrm{c} \\
(\mathrm{MPa})\end{array}$ & 0.509 & 0.281 & 0.079 & 0.311 & 0.069 & 0.055 \\
\hline $\begin{array}{c}\text { Global } \\
\text { strength } \sigma \mathrm{cm} \\
(\mathrm{MPa})\end{array}$ & 3.000 & 1.377 & 0.639 & 1.503 & 0.670 & 0.445 \\
\hline $\begin{array}{c}\text { Young's } \\
\text { modulus } \\
\text { Erm }(\mathrm{MPa})\end{array}$ & 431.99 & 197.99 & 108.76 & 197.48 & 65.18 & 60.49 \\
\hline
\end{tabular}

\section{IN-SITU ROCK-MASS STRENGTH PROPERTIES}

The first task in applying these models is to make an initial estimate of the range of potential strength and stiffness properties for the various major rock units present. This is done by assuming a failure criterion for the rock and by estimating the strength properties using the geotechnical characterization and available laboratory-testing data (Gönen and Köse, 2011; Malli et al, 2017).

\section{A. Failure Criteria}

The Hoek-Brown failure criterion is a commonly accepted method for estimating the relation of the principal stresses at failure for a rock mass. Hoek-Brown (1997) studied a relation failure conditions for rocks under stressing forces. They used trial and error methodology and found that the relation between the major principal stress and the minor principal stress is curve linear. The failure criterion relates the major principal stress $\left(\sigma_{1}\right)$ to the minor principal stress $(\sigma 3)$ at failure. The Equation (1) describing the criteria is given below.

$$
\begin{aligned}
& \sigma_{1}=\sigma_{3}+\sqrt{\left.m_{b} \sigma_{3} \sigma_{c}+s{\sigma_{c}}^{2}\right)} \\
& \mathrm{mb}=\operatorname{mi} \exp \left(\frac{R M R-100}{28}\right) \\
& \mathrm{s}=\exp \left(\frac{R M R-100}{9}\right)
\end{aligned}
$$

where is the Hoek-Brown constant for the particular rock type, and s depends on the characteristics of the rock mass. The value $\sigma c$ : is the uniaxial compressive strength of the intact rock. The calculation of the mb, and s parameters is based on the degree of jointing and the alteration of joint surfaces reflected in the value of the RMR in Equation (2) and Equation (3).

\section{B. Goaf Materials}

Modeling of the gob area is another important step that affects the accuracy of the obtained results. It is rather difficult to model gob material by numerical analyses. Since gob is mainly made of broken rock pieces, its deformational properties are complex due to an ongoing consolidation process with an increase in the amount of load. Xie et al. (1999) suggested the Equation (4) for determination of the modulus of elasticity of gob material with respect to time.

$$
\mathrm{E}=15+175(1-\mathrm{e}-1.25 \mathrm{t}) \mathrm{MPa} \text { where; } \mathrm{t} \text { : is the time }
$$

Kose and Cebi (1988) suggested an interval of 15-3500 MPa for elasticity modulus value of gob material. On the other hand Yavuz and Fowell (2001) suggested a Poisson's ratio of 0.495 for gob material of the Tuncbilek Region. These values were used in order to find properties of gob material throughout the analyses. In addition, Salamon (1990); Kvapil, (1992); Pappas and Mark (1993); Yavuz (2004) may be used to describe the stress-strain behavior of goaf material. Determination of the two parameters, $\mathrm{Em}$ and Eo; is essential to describe the complete stress-strain curve for a site-specific caved rock material. Em merely depends on the initial bulking factor, b; and it can be determined as given in Equation (5) and Equation (6).

$$
\begin{aligned}
& \varepsilon \mathrm{m}=\frac{b-1}{b} \\
& \sigma=\frac{E o \varepsilon}{1-\varepsilon / \varepsilon m}
\end{aligned}
$$

where $\sigma$ : is the uniaxial stress applied to the material, $\varepsilon$ : the strain occurring under the applied stress, Eo: is the initial tangent modulus and $\mathrm{Em}$ : is the maximum possible strain of the bulked rock material.

\section{NUMERICAL MODELS}

LTCC method has many advantageous in production of thick coal seams. However due to production losses in caving and dilution other thick coal seam production methods should also be examined. During this examination mostly production characteristics are considered and rock mechanics characteristics are examined very little. In this study, for Omerler region, three different production methods are compared in the terms of rock mechanics using numerical models. Average thickness of the seam is $8 \mathrm{~m}$. Bottom face, lower-upper face and three slice production are evaluated in terms of rock mass.

LTCC method has many advantageous in production of thick coal seams. However due to production losses in caving and dilution other thick coal seam production methods should also be examined (Yavuz, 2003; Yasitli and Unver, 2005; Xie and Zhao, 2009; Xie et al, 2009; Saeedi et al, 2010; Vakili and Hebblewhite, 2010; Yan et al, 2013; Wang et al., 2014). During this examination mostly is considered production methods of thick coal seam and rock mechanics.

\section{A. LTCC from Bottom Face}

In this method, $3 \mathrm{~m}$ of $8 \mathrm{~m}$ seams is produced by bottom face. The rest $5 \mathrm{~m}$ is produced by caving from back face. Vertical 
stresses, vertical displacements and maximum shear strains are evaluated with numerical models in this method.

When vertical stresses are considered in bottom face, the maximum value of stress is found to be $8.5 \mathrm{MPa}$. This value occurs in $3 \mathrm{~m}$ advance from the face. When the point after $3 \mathrm{~m}$ advance is considered, stress is found to be $7.5 \mathrm{MPa}$ and then 6 $\mathrm{MPa}$. It stays constant at $6 \mathrm{MPa}$. The stress just on top of the face is $1 \mathrm{MPa}$. The stress on the back face starts from $2.5 \mathrm{MPa}$ and increases up to $3 \mathrm{MPa}$. Then is stays constant at $3 \mathrm{MPa}$ (Figure 5-a). Vertical displacement can be seen in Figure 5-b. This value is between $17-23 \mathrm{~cm}$ in front face where stress is high. It is between $35-67 \mathrm{~cm}$ on the face and $29-65 \mathrm{~cm}$ at the caved zone. In Figure 5-c, zones where maximum shear strain appears can be seen. In front face where maximum vertical stress appears, the strain value is $0.014 \mathrm{MPa}$ and it is $0.011 \mathrm{MPa}$ and $0.007 \mathrm{MPa}$ even further. The strain value changes between $0.007 \mathrm{MPa}$ and $0.011 \mathrm{MPa}$ on the face and it changes between $0.028 \mathrm{MPa}$ and $0.048 \mathrm{MPa}$ at the caved zone.
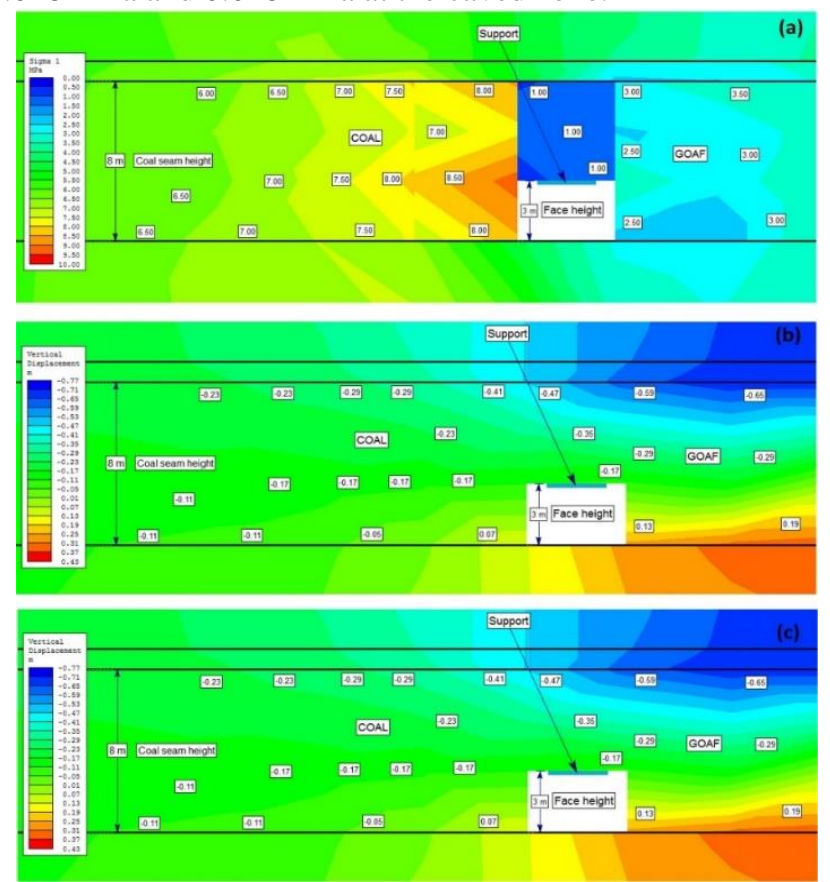

Figure 5. Vertical stress distribution (a), Vertical displacements (b), Maximum shear strains (c) around the bottom face

\section{B. LTCC from Lower Face in Lower-Upper Face Method}

LTCC from lower face in lower-upper face method, the stress is $1.10 \mathrm{MPa}$ and $7.15 \mathrm{MPa}$ on the upper face and in front of face respectively. In addition it is found to be $7.50 \mathrm{MPa}$ in front of lower face. The stress on the lower face turned out to be 3.85 $\mathrm{MPa}$ due to the caving of upper face. Vertical stress is found to be $4.45 \mathrm{MPa}$ at the caving side of upper face and $3.30 \mathrm{MPa}$ at the caving side of lower face. The distance between the two faces is $38 \mathrm{~m}$. No stress is observed in the $2 \mathrm{~m}$ zone of coal between the two faces. However 5.5 MPa stress is observed in the middle zone and $3.85 \mathrm{MPa}$ is observed upper face (Figure 6-a). In the lower-upper face method, $18 \mathrm{~cm}, 7 \mathrm{~cm}$ and $4 \mathrm{~cm}$ displacements are observed on the upper face in front of upper face and on the caving zone respectively. In addition $18 \mathrm{~cm}, 4$ $\mathrm{cm}$, and 4-21 cm vertical displacements are found on the lower f Maximum shear strains can be seen in Figure 6-c. Shear stresses are found to be $0.006 \mathrm{MPa} 0.015 \mathrm{MPa}$ and $0.033 \mathrm{MPa}$ on the upper face, in front of upper face and in the caving zone of upper face respectively. When lower face is considered, shear stresses turned out to be $0.012 \mathrm{MPa}, 0.012 \mathrm{MPa}$ and 0.033 $\mathrm{MPa}$ on the face, in front of face and on the caving zone respectively. The shear stress throughout the $38 \mathrm{~m}$ distance between the two faces is $0.009 \mathrm{MPa}$. Face, in front of lower face and on the caving zone of lower face respectively (Figure 6-b).
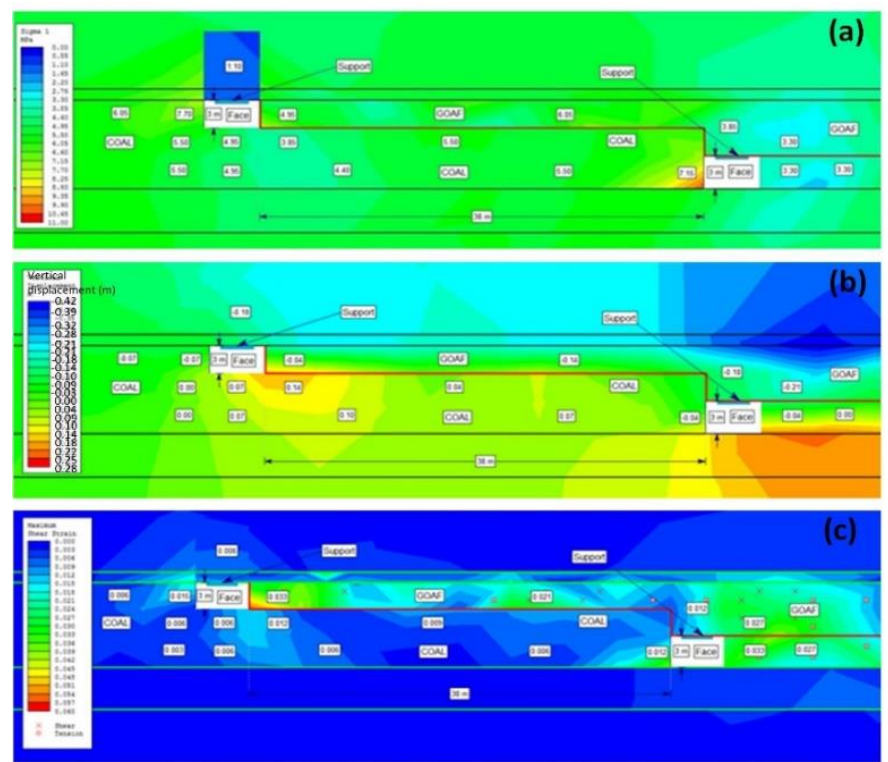

Figure 6. Vertical stress distribution (a), Vertical displacements (b), Maximum shear strains (c) around the lower-upper face

\section{Multi-slice Longwall Method}

In multi-slice longwall method, the vertical stress is found to be $2 \mathrm{MPa}$ on the top face, $7 \mathrm{MPa}$ in front of the top face and 5.5 $\mathrm{MPa}$ on the caving zone. When the middle slice is considered vertical stresses are found to be 1-5 $\mathrm{MPa}, 6.5 \mathrm{MPa}$ and $6 \mathrm{MPa}$ on the face, in front of face and on the caving zone respectively. Finally, in the lower face vertical stresses are $3 \mathrm{MPa}, 6.5 \mathrm{MPa}$ and $5.5 \mathrm{MPa}$ on the face, in front of face and on the caving zone respectively (Figure 7-a).
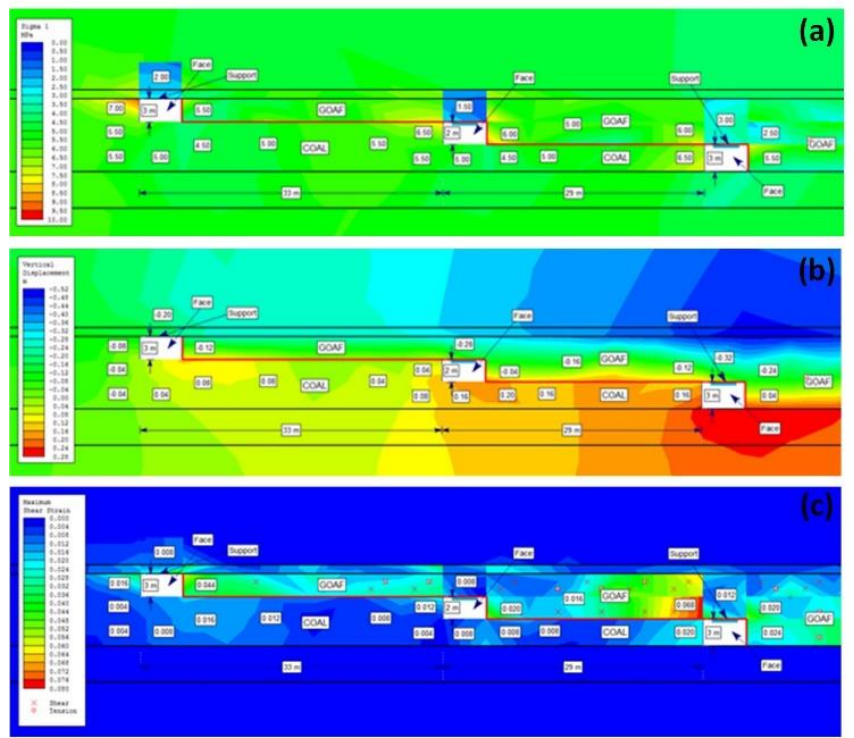

Figure 7. Vertical stress distribution around the multi-slice longwall face 
The distance between the faces is $30 \mathrm{~m}$ and vertical stress does not increase in this region. Displacements in multi-slice longwall method are found $20 \mathrm{~cm}$ on the first face, $28 \mathrm{~cm}$ above the second face and $12 \mathrm{~cm}$ on the caving zone of above third face. Similarly vertical displacements in the middle face turned out to be $28 \mathrm{~cm}, 4 \mathrm{~cm}$ and $4 \mathrm{~cm}$ on the face in front of face and on the caving zone respectively. When lower face is considered, displacements are $32 \mathrm{~cm}$ on the face, $16 \mathrm{~cm}$ in front of face and $4 \mathrm{~cm}$ on the caving zone. Maximum displacement is observed as $25-28 \mathrm{~cm}$ on the lowest region of lower face (Figure 7-b).

Maximum shear strains can be seen in Figure 7-c. The shear stress on the top of face is $0.008 \mathrm{MPa}, 0.016 \mathrm{MPa}$ in front of the top of face and $0.044 \mathrm{MPa}$ on the caving zone. When middle slice is considered, shear stresses are $0.008 \mathrm{MPa}, 0.012 \mathrm{MPa}$ and $0.020 \mathrm{MPa}$ on the face. In front of face and on the caving zone respectively. In the lower face, shear stress values are found to be $0.012 \mathrm{MPa}$ and $0.024 \mathrm{MPa}$ respectively. The maximum shear stress values are observed in front of the lower face as $0.008 \mathrm{MPa}$.

\section{RESULTS AND DISCUSSION}

In thick coal seams, lower face, lower-upper face and sliced methods are the mostly used production methods. In this study, data obtained from field studies and laboratory experiments belonging to all three methods are considered and modelled using Phase2D. The results achieved for all three methods support plastic cover layer theory defined in Jacobi 1976, Peng \& Chiang 1989 and Hudson 1993. Maximum vertical strain measured on the coal seam located in front of the longwall is 9.5 $\mathrm{MPa}$ (Figure 8). In this case, strain values in front of face exceed gravity pressure $(6 \mathrm{MPa})$ by $25 \%$. This value decreases to $16.67 \%$ (1 MPa) inside the face.

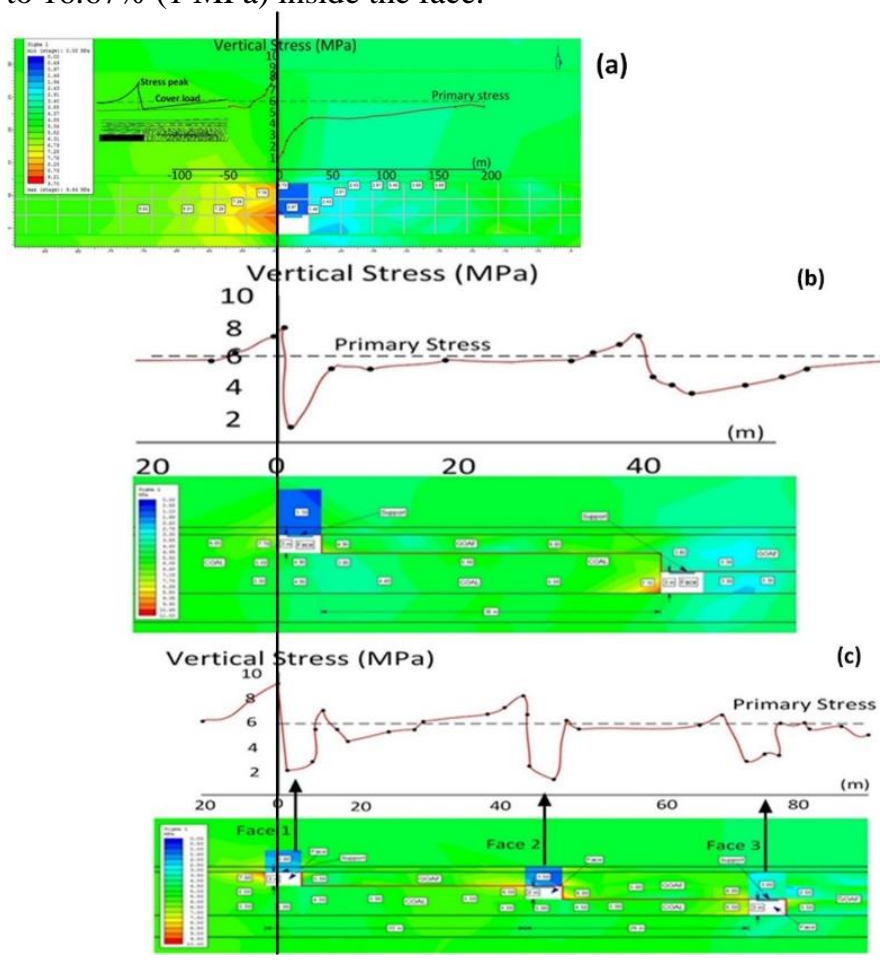

Figure 8. Vertical stress distribution surrounding bottom face (a), lower-upper face (b), Multi Slice Longwall Face (c)
Strain distribution occurring in lower-upper face method is basically coherent with lower face method. Maximum vertical strain on the coal seam in front of top face and bottom face are computed to be $7.70 \mathrm{MPa}$ and $7.15 \mathrm{MPa}$, respectively. Strain forces effective on gob area behind the upper face increase gradually as the gob advances and reaches up to gravitational strain value at about $20 \mathrm{~m}$ behind the face (Figure 8b). On the other hand, in lower face method, these forces reach up to gravitational strain value at $150 \mathrm{~m}$ behind the face (Figure 8a). This difference is to the additional strain forces caused by lower face.

In multi slice method, maximum vertical strain measured on the top longwall, middle longwall and bottom longwall are $7 \mathrm{MPa}$, 6.5 $\mathrm{MPa}$ and 6 $\mathrm{MPa}$ respectively (Figure 8c). Strain values decrease gradually from top to bottom. According to these measures, strain decreases by $7.14 \%$ from the first slice to the second slice. In addition, strain decreases by $14.29 \%$ from the first slice to the third slice. This is because, 2nd and 3rd slice are on the zone of relaxation of the first slice.

\section{CONCLUSION}

Numerical modeling is an important and useful method in order to determine roof support dimensions. It is also beneficial in order to see work safety of production methods, to examine whether, the roof supports are sufficient and to be more careful in points with maximum stress values.

Production methods used in thick coal seams are analyzed according to strain forces using Phase2D modelling. Similar strain values are computed in front of the face in all three methods considered. However, when strain values on the gob area are measured, strain distribution in lower face method is found to be more stabilized and proper.

\section{REFERENCES}

[1]. Alemdag, S., Kaya, A., Karadag, M., Gurocak, Z. and Bulut, F. (2015) Utilization of the limit equilibrium and finite element methods for the stability analysis of the slope debris: An example of the Kalebasi District (NE Turkey). Journal of African Earth Sciences, 106, pp:134 146.

[2]. Bieniawski. ZT. Engineering classification of jointed rock masses Trans S Afr Inst Civ Eng 1973; 15:335-44

[3]. Bieniawski. ZT. Engineering rock mass classifications, a complete manual for engineers and geologists in mining, civil and petroleum engineering. New York: Wiley; 1989 251pp.

[4]. Destanoglu N, Taskin FB, Tastepe M, Ogretmen S., (2000). Omerler mechanized longwall application, Turkish Coal Administration, Ankara (in Turkish).

[5]. Folorunso, A F., Yuguo, L. and Liu, Y. (2015). Characteristics of marine CSEM responses in complex geologic terrain of Niger Delta Oil province: Insight from 2.5D finite element forward modeling. Journal of African Earth Sciences, 102, pp: 18-32.

[6]. Gönen, A., Köse, H. (2011). Stability Analysis of Open Stopes and Backfill in Longhole Stoping Method for Asikoy Underground Copper Mine. Arch. Min. Sci., Vol. 56 (2011), No 3, p. 375-387.

[7]. Hartman, H.L., Mutmansky, J. M., (2002). Introductory Mining Engineering, 2nd Edition, ISBN: 0-471-34851-1, p. 584

[8]. Hebblewhite, B.K., Cai, Y.I., (2004). Evaluation of the Application of the Longwall Top Coal Caving (LTCC) Method m Australia, UNSW Mining Research Centre School of Mining Engineering, Sydney, Australia.

[9]. Hudson, J. A. (1993) Comprehensive Rock Engineering, Vol2+5. Pergamon Press.

[10]. Hoek E., Strength of rock and rock masses. ISRM News J 1995 2(2):4-16. 
[11]. Hoek E, Brown ET. Practical estimates of rock mass strength. Int J Rock Mechanics Mining Science 1997; 34(8):1165-86.

[12]. IEA (International Energy Agency), (2013c). Coal Information 2013 , Paris.

[13]. Jacobi, O, (1976). Praxis der Gebirgsbenherrschung, Verlag Gluckauf, Esen.

[14]. Kanık, M., Gurocak, Z. and Alemdag, S. (2015). A comparison of support systems obtained from the RMR89 and RMR14 by numerical analyses: Macka Tunnel project, NE Turkey. Journal of African Earth Sciences, 109, pp: 224-238.

[15]. Kose, H., Cebi, Y., (1988). Investigation the stresses forming during production of thick coal seam. 6th coal congress of Turkey, Zonguldak, pp. 371-383 (in Turkish).

[16]. Köse, H., Tatar, Ç., Konak, G., Onargan, T., Kızıl, M.S., (1994). T.K.İ Garp Linyitleri İsletmesi Müessese Müdürlüğü Ömerler Yeralt İsletmesi Tabaka Kontrolü Yük ve Konverjans Ölçümleri, Dokuz Eylül Üniversitesi Mühendislik Fakültesi Maden Mühendisliği Bölümü, Proje Raporu.

[17]. Kose H, Tatar C. Underground mining methods. Izmir: DEU; 2011 (in Turkish).

[18]. Kvapil R., (1992). Sublevel caving, SME mining engineering handbook, pp. 1789-814.

[19]. Mallı, T., Yetkin, M. E., Özfirat, M. K., Kahraman, B. (2017). Numerical analysis of underground space and pillar de sign in metalliferous mine. Journal of African Earth Sciences 134, 365-372.

[20]. Ozfirat M. K. (2007). Investigations on Determining and Decreasing the Coal Loss At Fully-Mechanized Production in Omerler Underground Coal Mine, PhD Thesis, Institute of Natural and Applied Sciences, Dokuz Eylul University, Izmir (in Turkish).

[21]. Pappas DM, Mark C., (1993). Behavior of simulated longwall gob material. Report 9458. United States Department of the Interior-Bureau of Mines.

[22]. Peng SS, Chiang HS., Longwall mining. New York: Wiley; 1984

[23]. Phase2 8, Version 8.020-2014, Rocscience Inc, Toronto, Ontario, Canada.

[24]. RocData, 5.0 (2014). Rock, Soil and Discontinuity Strength Analysis, Version 5.0.

[25]. Saeedi, G., Shahriar, K., Rezai, B., Karpuz, C., (2010). Numerica modelling of out-of-seam dilution in longwall retreat mining, International Journal of Rock Mechanics \& Mining Sciences 47, pp. 533-543.

[26]. Salamon MDG., (1990). Mechanism of caving in longwall mining. In: Hustrulid W, Johnson G, editors. Rock mechanics contributions and challenges. Proceedings of the 31st US rock mechanical symposium, Golden, Colorado, Rotterdam, Balkema, p. 161-168.

[27]. Simsir, F., Ozfirat, M.K., (2008). Determination of the most effective longwall equipment combination in longwall top coal caving (LTCC) method by simulation modelling, International Journal of Rock Mechanics \& Mining Sciences 45, pp. 1015-1023.
[28]. Singh, R., Singh, T.N., (1999). Investigation into the Behavior of Support System and Roof Strata during Sublevel Caving of a Thick Coal Seam, Geotechnical and Geological Engineering 17 21-35, Netherlands.

[29]. Sonmez H, Ulusay R., (1999). Modifications to the Geological Strength Index (GSI) and their applicability to stability of slopes. Int J Rock Mech Min Sci; 36(6):743-60.

[30]. Taskin FB., (1999). Optimum dimensioning of pillars between longwall panels in Tuncbilek Mine, PhDthesis, Osmangazi University, Eskisehir, p 149 (in Turkish).

[31]. Xie, H., Chen, Z., Wang, J., (1999). Three-dimensional numerica analysis of deformation and failure during top coal caving, International Journal of Rock Mechanics and Mining Sciences 36, pp. 651-658.

[32]. Xie, Y.S., Zhao, Y.S., (2009). Numerical simulation of the top coal caving process using the discrete element method, International Journal of Rock Mechanics \& Mining Sciences 46, pp. 983-991.

[33]. Xie, G.X., Chang, J.C., Yang, K., (2009). Investigations into stress shell characteristics of surrounding rock in fully mechanized top-coal caving face, International Journal of Rock Mechanics \& Mining Sciences 46, pp. 172-181.

[34]. Vakili, A., Hebblewhite, B.K., (2010). A new cavability assessmen criterion for Longwall Top Coal Caving, Int. Journal of Rock Mechanics \& Mining Sciences 47, pp. 1317-1329.

[35]. Wang, S., Ni, P., (2014). Application of block theory modeling on spatial block topological identification to rock slope stability analysis. International Journal of Computational Methods, $\mathrm{V}: 11, \mathrm{~N}: 1$

[36]. Wang, J., Yang, S., Li, Y., Wei, L., Liu, H., (2014). Caving mechanisms of loose top-coal in longwall top-coal caving mining method, International Journal of Rock Mechanics \& Mining Sciences 71, pp. $160-170$.

[37]. Yan, S., Bai, J., Wang, X., Huo, L., (2013). An innovative approach for gateroad layout in highly gassy longwall top coal caving, International Journal of Rock Mechanics \& Mining Sciences 59, pp $33-41$.

[38]. Yasitli NE., (2002). Numerical modeling of longwall with top coa caving. MSc. Thesis, Hacettepe University, Ankara, p. 148 (in Turkish).

[39]. Yasitli NE, Unver B., (2005). 3D numerical modeling of longwal mining with top-coal caving, Int J Rock Mech Min Sci, 42(2):219-35.

[40]. Yavuz H, Fowell RJ., (2001). Softening effect of coal on the design of yield pillars. In FLAC and numerical modelling in geomechanics. In Lyon, France D, Billaux et al, editors. Proceedings of the 2nd international FLAC conference, Lisse, A.A. Balkema, p. 313-20.

[41]. Yavuz, H., (2004). An estimation method for cover pressure reestablishment distance and pressure distribution in the goaf of longwall coal mines, International Journal of Rock Mechanics \& Mining Scienc s 41, 193 - 205 . 